\title{
NUEVO díA
}

\author{
Mauricio Beuchot
}

\section{1.}

Sol entre lluvia, cosa tan extraña.

Nubes equivocadas

refulgen y se iluminan,

a pesar de la borrasca

en medio de la cual brilla

la luz, perdida.

Claroscuro húmedo, luces de sol y sombras de nubes

de tormenta, enredadas.

Brillos erráticos, engastados en las gotas de agua.

Tormenta iluminada, irradiando luces por las grietas de las nubes, de tiniebla apretada.

Y yo, en medio de esa contienda de opuestos, luz y tinieblas, brillos y sombras, iluminado y asombrado, entre luces y sombras en desbandada. 
Sol en la borrasca, entre nubes oscuras y lluvia equivocada. El sol brilla sin saber cómo, y avasalla.

De pronto, una tormenta de fuego, en la tempestad iluminada. En cada gota de lluvia el sol brillaba.

Y cada gota, un mundo, y cada brillo, una ráfaga de la luz del universo, condensada.

Claroscuro, de la realidad extraviada, como una lluvia que tuviera al sol en su entraña. 
Árboles por la tarde, con el sol en las ramas.

Cada hoja es un brillo, refulge como ascua, y el árbol, incendiado, es una viva brasa.

Entre la sombra que da el árbol, y la luz que proyecta, se da una sensación de llamarada.

Árboles por la tarde, ustedes tienen luz y sombra en las ramas.

\section{4.}

Vivir en el borde, en el borde de todo, en la orilla del todo, en su horizonte.

Destellos apagados.

Son palabras rescoldo, que fenecen.

Estar en el borde, en el límite del lenguaje, donde se toca con el mundo. Asomarse al cosmos, desde el lado lingüístico, tocar las cosas desde las palabras. En el pliegue del lenguaje y del mundo, en el que los dos se encuentran. 


\section{5.}

A caballo entre dos siglos, el XX y el XXI;

nacido en la mitad del primero y no sé hasta cuándo del segundo, tengo mis raíces hundidas en el XX y mis ramas proyectadas hacia el XXI. No sé a cuál de los dos pertenezco, cada uno tan distinto y ambos tan impredecibles, tan llenos de misterio.

Batallé en el XX, y ahora, en mi tercera edad, estoy disfrutando el XXI, cosechando los frutos inesperados del anterior, lleno de ahorros.

Apasionante siglo XX, tan difícil, impredecible siglo XXI, tan extraño y tan nuevo. $Y$ yo en medio, sin entender a ninguno, pero sonriendo. 


\section{6.}

Fundamento desfundado, hontanar sin fondo:

como eso

vieron a Dios los místicos, y nosotros

así vemos, ahora, el ser.

Como mar sin orillas y

como esfera sin centro, o cuyo centro

en todas partes se esparce:

así vieron los místicos a Dios, y nosotros

así vemos al ser, ahora.

En ambos casos, igual.

La única diferencia

es que ellos saltaron al vacío,

dieron ese salto que el bueno

de Kierkegaard nunca se atrevió a dar.

Extendiendo hasta acá sus brazos,

en el tiempo,

los místicos llegan a nosotros,

desconstruyen a Derrida, y lo dejan chiquito.

(Como dice un amigo mío:

el mayor desconstruccionista de la historia

ha sido San Juan de la Cruz, ese sí no dejó nada).

Los místicos eran buenos ontólogos, los mejores: juntaban el mito y la filosofía, de modo que uno a otro se enriquecían, se engendraban.

Desconstruyen la desconstrucción, le regalan un sentido. 
La vuelven auténtica, la sopesan, la recogen, la levantan, la limpian y la orientan. Rasgan el ser, lo ponen al revés, esto es, como debería estar, en el sentido propio (no con las tibiezas y delicadezas, modosas y amaneradas, de nuestros desconstructores oficiales, petimetres al uso, deseosos de aplauso).

Sobre todo, los místicos dejan que el ser sea, lo aguantan, lo recobran del tiradero en el que fue dejado por la ciencia y la técnica.

Ser de desperdicio, lo curan y lo reparan, como el buen samaritano que recogió y cuidó a aquel que dejaron casi muerto.

Ser que es límite sin límite, pues pega junto al hombre, que es tan extralimitado. Un infinito junto a otro (uno en extensión, en profundidad el otro, pero ambos infinitos). Límite sin limitación, que solo podemos ver donde el hombre y el mundo se juntan, donde el microcosmos y el macrocosmos se tocan. 


\section{7.}

Pienso en Nicolás de Cusa:

"Lo mínimo y lo máximo se encuentran

en el infinito".

Que lo máximo es Dios, no cabe duda.

El hombre es lo mínimo, pero es

un mínimo infinito.

No un infinito de minucia, no;

sino una minucia infinita, porque

tiene un infinito potencial

dentro de su mente,

en el infinito actual

que es la Mente Divina.

Oh, vértigo luminoso,

un infinito hacia adentro,

de ideas que se suceden y se reflejan,

las unas en las otras.

106 Resuena Aristóteles: "El hombre es

de alguna manera todas las cosas".

$Y$ es que lo es por su mente,

otra vez, en potencia,

para ser todo lo que comprende,

o incluso imagine, o sospeche.

Infinito paradigmático,

no sintagmático;

infinito de asociaciones, de

evocaciones, de ideas y palabras

que se jalonan y se arrastran,

seducidas por su canto.

Infinito de rumores, de

sugerencias, de connotaciones

que encierran las palabras, ellas solas, sin que puedan acabar nunca. 
Y ese infinito, encerrado en el hombre -por eso microcosmos-, se asoma a los ojos, se asoma a la lengua, y con el otro infinito, se toca.

Creando un límite, esto es, una finitud, entre los dos infinitos; no se repelen, se tocan en ese límite. Nos reducen a él, lo hacen reducto de nuestra dispersión y nuestra locura, y nos colocan, nos sitúan.

Finitud del entrecruce de los dos infinitos, lugar de encuentro, finito y pequeño, pero suficiente. Así es el hombre. 
CITAM Derechos Reservados.

La reproducción total o parcial de este artículo se podrá hacer si el ITAM otorga la autorización previamente por escrito. 